\title{
SOME FOOD PIOSONING ORGANISMS IN STREET- VENDED ICE CREAM IN ALEXANDRIA
}

\author{
A.S. Aiad ${ }^{*}$ and M.A. Ewina** \\ * Animal Health Research Institute (Alexandria branch) \\ ** Animal Health Research Institute (Kafr El-Sheikh branch)
}

\begin{abstract}
Although ice cream is widely used allover the world especially in summer season and considered palatable to consumers especially children, it may constitute a serious public health hazard due to its contamination from a variety of sources with different types of microorganisms. Sixty random samples of frozen ice cream with chocolate, strawberry and vanilla flavor (20 each) were collected from street-vendors and hawkers in Alexandria city. The samples were examined for the incidence of some food poisoning organisms in ice cream products. The incidence of Bacillus cereus in the examined samples of street-v ended frozen ice cream with chocolate. strawberry and vanilla flavor was 20,25 and $15 \%$. respectively. Clostridium perfringens was detected in 10,15, and $10 \%$ of examined ice cream, respectively. The mean counts of Enteropathogenic Escherichia coli (cfulg) $l .22 \times 10^{4} \pm 0.4 \times 10^{4 ;} 4.1 \times 10^{4} \pm 0.54 \times 10^{4}$ and $1.08 \times 10^{4} \pm 6.3 \times$ $10^{3}$ with respective incidence of 20,25 and $15 \%$.Comparing the results with Egyptian standards (1993) which stipulate that ice cream must be free from Laureus, it is clear that 30, 25, $20 \%$ of examined street-vended ice cream samples with chocolate, strawberry and vanilla flavor did not comply with it, respectively. Yersinia enterocolitica could be isolated from only one \% of street-vended ice cream samples with strawberry. The importance of the concerned microorganisms as public health hazards and recommendations for control has been highlighted.
\end{abstract}

Key words: Clostridium pelfringens E. coil- Salmonella species- Yersinia suedes ice - cream.

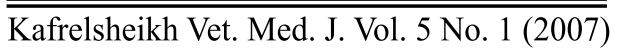




\section{INTRODUCTION}

Ice cream products are considered not only as a simple delicacy, but also as nutritional deserts containing dietary components that are important to both children and adults (Varnam and Sutherland, 1994). Frozen dairy products including ice cream are implicated as an important source of some pathogenic microorganisms constituting a serious threat to human health as public health surveillance reports documented that the number of ice cream related food poisoning outbreaks has steadily increased (Ryser, 1998 and Vought and Tatini, 1998).

Bacillus cereus is the causative agent of two distinct forms of gastroenteritis disease connected to food poisoning. The diarrheal syndrome which is characterized by abdominal pain and diarrhea, with an incubation period of 8 to 16 hours and symptoms that last 12 to 24 hours (Elating-Schulz et al, 2004 and Lindback et al.,2004) and the emetic syndrome is characterized by an acute attack of nausea and vomiting within 1-5 hours after a meal. The illness is relatively mild and recovery within 12-24 hours (Kawamura et al., 2005 and Taylor et al., 2005). Bacillus cereus has been reported as the causative agent in 1-22\% of food poisoning outbreaks in Europe, Japan and North America over a period 1960-1992(Pirhonen et al., 2005).

Presence of Clostridium perfringens in food is considered as indicative of nature and soil contamination and incriminated in food poisoning outbreaks (Hayes, 1992). It is implicated in human food poisoning outbreaks traced to consumption of milk and its products. Food poisoning occurs as a result of ingestion of contaminated food with large population of the microorganisms and subsequent liberation of their enterotoxins in intestine (Semedley et al., 2004). 
Many reports have been published earlier worldwide on the incidence of Clostridium perfringens in dairy products by several investigators (Dalton et al., 2004; Fukao et al, 2004 and Nakamura et al, 2004).

Enteropathogenic Escherichia coli (EPEC) has been implicated in human cases of gastroenteritis with symptoms of malaise, vomiting, diarrhea with stool containing mucous but rarely blood appear 12-36 hours after ingestion of food (Adams and Moss, 2000).

Contamination of food with S.aureus has been implicated in gastroenteritis in spite of advances achieved in dairy technology. Several outbreaks of staphylococcal food poisoning have been recorded, involving large number of people throughout the world (Adams and Moss, 2000 and Holeckova et al., 2002).

Yersinia enterocolitica is a zoonotic, Gram-negative bacterium capable of causing severe gastrointestinal infection (Butler, 1998). It produces a heat stable enterotoxin that is associated with food poisoning symptoms in man (Quinn et al, 1994). The predominant disease caused by pathogenic strains of Yersinia eni erocolitica is enterocolitis, which accounts for two-thirds of reported cases especially in young children and characterized by fever and diarrhea, which frequently accompanied by abdominal pain lasting 1-3 weeks (Marks, 1980). Sometimes, Yersinia enterocolitica causes a syndrome which mimic appendicitis often in older children and young adults (Lamps et al, 2001).

Therefore, this work was accomplished to secure information regarding the incidence of some food poisoning organisms in ice cream products currently available at the retail level in Alexandria city. 


\section{MATERIAL AND METHOD}

\section{Collection of samples:}

Sixty random samples of street-vended ice cream with chocolate, strawberry and vanilla flavor (20 each) were collected from streetvendors and hawkers in Alexandria city.

\section{Preparation of samples:}

The samples were left to melt in a thermostatically controlled water bath at 44UC for not more than 15 minutes. Each sample was then thoroughly mixed using a sterile stirrer before being examined. Eleven grams of each sample was diluted in $99 \mathrm{ml}$ of peptone water $0.1 \%$ from which decimal dilutions were prepared (APHA, 1992).

\section{Enumeration and isolation of Bacillus cereus:}

It was preformed by using direct plating using PEMBA agar. Suspected colonies were picked up for further confirmation according to Kramer et al.,(1982).

\section{Enumeration and isolation of Clostridium perfringens:}

It was performed by using direct plating using Sulphite Polymyxin Sulfadiazine (SPS) agar as recommended by Angelotti et al, (1962). Suspected colonies were picked up for further confirmation according to Mead et al,(1981).

5. Enteropathogenic Eseherichia coli count (APHA, 1992).

5.1. Serological identification of E. coil isolates (Edward and Ewing, 1972).

6. Staphylococcus aureus count (I. C.M.S.F., 1986).

7. Isolation and identification of Versinia species (FDA, 1998).

8. Salmonella species (Cox, 1988). 


\section{RESULTS}

Table (1): Incidence and counts of some food poisoning microorganisms in street-vended ice cream samples (n 60).

\begin{tabular}{||c||c|c||c|c||c|c||}
\hline \multirow{2}{*}{ Flavor } & \multicolumn{2}{|c||}{ Chocolate $(\mathbf{n = 2 0})$} & \multicolumn{2}{c||}{ Strawberry $(\mathbf{n = 2 0})$} & \multicolumn{2}{c||}{ Vanilla $(\mathbf{n}=20)$} \\
\hline counts & $\%$ & Mean \pm SEM & $\%$ & Mean + SEM & $\%$ & Mean SEM \\
\hline \hline Bacillus cereus & 20 & $4.15 \times 10^{3} \pm 1.1 \times 10^{3}$ & 25 & $6.5 \times 10^{3} \pm 2.4 \times 10^{3}$ & 15 & $2.3 \times 10^{3} \pm 0.33 \times 10^{3}$ \\
\hline CI.perftingens & 10 & $1.1 \times 10^{2} \pm 0.52 \times 10^{2}$ & 15 & $2.15 \times 10^{2} \pm 3.2 \times 10$ & 10 & $7.5 \times 10 \pm 0.5 \times 10$ \\
\hline EPEC & 20 & $1.22 \times 10^{4} \pm 0.4 \times 10^{4}$ & 25 & $41 \times 10^{4} \pm 0.54 \times 10^{4}$ & 15 & $1.08 \times 10^{4} \pm 6.3 \times 10^{3}$ \\
\hline S. aureus & 30 & $2.07 \times 103 \pm 1.07 \times 103$ & 25 & $5.01 \times 10^{3} \pm 1.43 \times 10^{3}$ & 20 & $1.14 \times 10^{3}+0.4 \times 10^{3}$ \\
\hline Y. enterocolitica & 0 & ---------------- & $I$ & ---------------- & 0 & ----------------- \\
\hline Salmonella & 0 & --------------- & 0 & -------------- & 0 & ----------------- \\
\hline
\end{tabular}

$\mathrm{SEM}=$ Standard error of mean .

Table (2): Frequency distribution of EPEC serotypes isolated from positive street-vended ice cream samples.

\begin{tabular}{||c||c||c||}
\hline Serotype & No. & \% \\
\hline \hline $\mathrm{O}_{26}: \mathrm{K}_{60}: \mathrm{B}_{6}$ & 3 & 23.08 \\
\hline $\mathrm{O}_{86}: \mathrm{K}_{61}: \mathrm{B}_{7}$ & 2 & 15.38 \\
\hline $\mathrm{O}_{114}: \mathrm{K}_{90}: \mathrm{B}_{-}$ & 2 & 15.38 \\
\hline $\mathrm{O}_{119}: \mathrm{K}_{69}: \mathrm{B}_{14}$ & 1 & 7.69 \\
\hline $\mathrm{O}_{125}: \mathrm{K}_{70}: \mathrm{B}_{15}$ & 1 & 3.69 \\
\hline Untypable strains & 4 & $\mathbf{1 0 0}$ \\
\hline \hline Total & $\mathbf{1 3}$ & 30.77 \\
\hline
\end{tabular}

$\%$ The precentagy were estimated according to the total number of the isolates.

$\overline{\text { Kafrelsheikh Vet. Med. J. Vol. } 5 \text { No. } 1 \text { (2007) }}$ 


\section{DISCUSSION}

Ice cream is the most popular frozen dairy product widely used all over the world due to its high nutritive value and its palatability to consumers at all ages. However, it is worth to mention that ice cream may constitute a serious public health hazard due to its contamination with a variety of pathogenic microorganisms which may gain entrance to ice cream through using inferior quality raw material, insufficient heat treatment of milk or contaminated equipment used for its preparation and distribution.

\section{Bacillus cereus:}

Data summarized in Table (1) showed that the majority of positive samples contaminated with Bacillus cereus were ice cream with strawberry flavor; lower counts were detected in ice cream with vanilla flavor. The obtained results indicated that ice cream could responsible for transmitting Bacillus cereus to consumers. The presence of high number of Bacillus cereus organisms in a variety of food has been found to associate with the production of either emetic or diarrhogenic. extracellular protein heat labile, toxins (Kawamura et al., 2005).

It was suggested that food industry should be concerned with level as low as I OK I $0^{4} / \mathrm{gm}$ food because food toxic infection may be caused by ingestion of Bacillus cereus cells or spores which subsequently form enterotoxin in the ileum (Granum el al., 1993). Furthermore, Becker et al., (1994) recorded that 54\% of infant food samples distributed in 17 countries were contaminated with diarrhogenic Bacillus cereus at level of $0.3-600 / \mathrm{gm}$.

\section{Clostridium perfringens:}

It is worth to mention that, the probability of food borne illness may occur to children due to consumption of contaminated products with

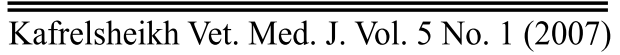


anaerobes which is indicative of careless methods of production (BouerHertzberger, 1982). Table (1) showed that Clostridiunz perfringens was detected in 10, 15, and $10 \%$ of examined ice cream with chocolate. strawberry and vanilla flavor, respectively.

\section{Enteropatbogenic Escherichia coli:}

The data present in Table (1) showed that the mean counts of Enteropathogenic Escherichia coli (cfu/g) in the examined street-vended ice cream samples flavored with chocolate, strawberry and vanilla were $1.22 \times 10^{4} \pm 0.4 \times 10^{4}, 4.1 \times 10^{4} \pm 0.54 \times 10^{4}$ and $1.08 \times 10^{4} \pm 6.3 \times 10^{3}$ with respective incidence of 20,25 and $15 \%$. The data present in Table (2) showed that the $E$. coli serotypes $\left(\mathrm{O}_{26}: \mathrm{K}_{60}: \mathrm{B}_{6}\right),\left(\mathrm{O}_{8}: \mathrm{K}_{.61}: \mathrm{B}_{7}\right)\left(\mathrm{O}_{114}: \mathrm{L}_{90}: \mathrm{B}_{-}\right)$ $\left(\mathrm{O}_{119}: \mathrm{K}_{69}: \mathrm{B}_{14}\right)$ and $\left(\mathrm{O}_{125}: \mathrm{K}_{70}: \mathrm{B}_{15}\right)$ were isolated from street-vended ice cream samples at incidence of 3 (23.08\%), 2 (15.38\%), 2 (15.38\%), 1 (7.69\%) and 1 (7.69\%), respectively, while four isolates of E. coli proved to be untypable.

The public health hazard of $E$. coli organisms has been emphasized by several investigators as they have been implicated in human cases of gastroenteritis, epidemic diarrhoea in infants, sporadic diarrhoea in children as well as food poisoning (DeBuyser et al., 2001).

\section{Staphylococcus aureus;}

The presence of S.aureus in ice-cram may originate from skin, mouth or nose of workers handling the food. S. aureus is a good indicator of the personal hygiene of workers with respiratory infection and suppuration (Kamat et al., 1991).

Comparing the results with Egyptian standards (1993) which stipulated that ice cream must be free from $£$ aureus, it is clear that 30 , $25,20 \%$ of examined street-vended ice cream samples with chocolate, strawberry and vanilla flavor did not comply with it, respectively. 
The growth of S.aureus in food products is a potential public health hazard since many strains can produce thermostable enterotoxins, which cause food poisoning, if ingested (Erkmen, 1995).

\section{Yersinia enterocolitica:}

Yersinia enterocolitica could be isolated from only one \% of streetvended ice cream samples with strawberry. This result is lower than those reported by EI-Kholy (1992); Khalil et al. (1993), ilenin and Kaldas (1995) and EI-Sherbini et al. (1999) with a rate of 6\%, 8\%, 8\% and $26.25 \%$, respectively. Serious cases may occur with rectal bleeding and perforation of the ileum (Rabinovitz, 1987). Moreover, there may be secondary immunologically mediated complications such as arthritis, erythema nodosum and to a lesser extent Reiter's syndrome, glomerulonephritis, myocarditis, exudative pharyngitis and septicaemia, which is less common and often reported in immunosuppressed individuals after contaminated blood products transfusion (Strobel et al, 2001). Salmonella failed to be detected in the examined samples of street-vended ice cream.

Although the results obtained showed lower contamination rates of pathogenic microorganisms in street-vended ice cream, it constitutes a high-risk hazard to consumers. The findings of the study warrant the need to undertake safety measures to avoid potential threats and apply educational programs for street-vended ice cream producers about the risk of contamination, how to prevent it and how to apply strict hygienic measures during production, storage and distribution of ice cream. Moreover, regulation of small-scale producing ice cream should be a part of a strategy to enhance producing of save and high quality ice cream in Alexandria city. 


\section{REFERENCE}

- Adams, M.S. and Moss, M.O. (2000): Food Microbiology $2^{\text {nd }}$ Ed. Royal Society of Chemistry. Thomas Graham House, Science Park, Milton Road Cambridge CB4OWF, UK.

- Angelotti, R.; Hall, H.E.; Foster, M.J. and Lewis, K.H. (1962): Quantitation of Clostridiumperfringens in foods. Appi. Microbiol. 10: 193-199.

- APHA (1992): Compendium of Methods for the Microbiological examination of Foods. $2^{\text {nd }}$ Ed., American Public Health Association. Washington, DC, USA.

- Becker, H.; Schaller, G.; Von Wiese, W. and Terplan, G.(1994): Bacillus cereus in infant foods and dried milk products. Int. J. Food Microbiol., 23: 1-15.

- Bouer-hertzberger, S.A.(1982): Food transmitted diseases of microbial origin. Ph.D. Thesis Ter Verkrvgring Van de Grand van in de diergeneeskunde aan de Priiks university Utrecht.

- Butler, T. (1998): Yersiniosis and plaque. In: ZoonosesBiology, Clinical Practice and Public Health Control.. Palmer. S.R.: Soulsby. L. and Simnson. D.I.H. (eds.). Oxford. 28 V293.

- Cox, N.A. (1988): Salmonella methodology update. Poultry Sci.. 67:921-927.

- Dalton, CB.; Gregory, J.; Kirk, MD.; Stafford, Rj.; Givney, R; Kraa, E. and Gould, D. (2004): Food borne outbreaks in Australia, 1995-2000. Commun. Dis. Intell. 28 (2): 211-24.

- DeBuyser, ML.; Dufour, B.; Maire, M. and Lafarge, V. (2001): Implication of milk and milk products in food-borne diseases in France.Int.J. Food Microbiol.20: 67(1/2): 1-17. 
- Edward, P.R. and Ewing, W.H. (1972): Identification of Enterobacteriaceae. 3rd Ed., Burgess Publishing Co., Minneapolis, Minnesota.

- Egyptian Standards (1993): Milk and Dairy Products. Part I: Ice cream. Egyptian Organization for Standardization and Quality Control. BOS: 1185.

- Ehling-Schluz, M.; Fricker, M. and Scherer, 5. (2004): Bacillus cereus, the causative agent of an emetic type of foodborne illness. Mol. Nutr. Food Res. 48(7): 497-87.

- EI-Kholy, A. M. (1992): Occurrence of Yersinia enterocolitica in ice cream and yoghurt. Assiut Vet. Med. J. 27, 108-1 13.

- El-Sherbini, M.; AI-Agili, S.; EI-Jali, H.; Aboshkiwa, M. and Koha, M. (1999): Isolation of Yersinia enterocolitica from cases of acute appendicitis and ice cream. East. Mediterr. Health. 5, 130-135.

- Erkmen, O. (1995): Behaviors of Staphylococcus aureus in Turkish feta cheese during manufacture and ripening. J. Food Prot.58 (11): 1201-1205.

- FDA (1998): Food and Drug Administration. Bacteriological analytical Manual. 8u Ed.. AOAC International, Gaithersburg, USA.

- Fukao, T.; Sato, M.; Tanaka, V. Monma, C. and Kato, N. (2004): An outbreak of diarrheal disease caused by Enterotoxigenic Clostridium perfringens following exposure to a contaminated environment in nursing home. Kansenshogaku Zasshi. 78 (1): 32-9. 
- Granum, P.E.; Brynestad, S.; O'Sullivan, K. and Nissen, $\boldsymbol{H}$. (1993): The enterotoxin from Bacillus cereus: Production and biochemical characterization. Neth. Milk daliry J. 47: 63-70.

- Hayes, P. R. (1992): Food Microbiology and Hygiene. $2^{\text {nd }}$ Ed., Elsevier Sci. Pub., LTD.. England.

- Henin, A.Y. and Kaldas, Y.T. (1995): Prevalence and characterization of Yersinia enterocolitica from raw milk and ice-cream in Minia city. J. Egypt. Vet. Med. Assoc. 55.59-66.

- Holeckova, B.; Holoda,E; Fotta,M.; Kalinacova, V.; Gondol, J. and Gronlus, J. (2002): Occurrence of enterotoxigenic Staphylococcus aureus in food. Ann. Agric. Environ. Med.9(2): 179-182.

- International Committee of Microbiological Specification for Foods, ICMSF (1986): Microorganisms in foods and sampling for microbiological analysis principles and specific applications.

- Kamat, M.Y.; Sulebele, G. and Nirupama, 5. (1991): A comparative evaluation of media for enumeration of enterotoxigenic Staphylococci by selective enrichment technique. J. Food Sci. Technol. India, 28 (6): 381-383.

- Kawamura, S. K.; Hirama, V.; Agata, N.; Ito, H.; Toni, K.; Takeno, A. Hasegawa, I.: Shimomura, V. and Ohta, M. (2005): Quantative analysis of cereulide, an emetic toxin of Bacillus cereus. by using rat liver mitochondria. Milcrobiol. Immunol. 49 (1): 25-30.

- Khalil, N.G.; Elyas, A.H. and Nashed, S.M. (1993): Studies on Yersinia enterocolitico in raw milk and ice cream. Assiut Vet. Med. J. 29, 103-109. 
- Kramer, J.M.; Turnbuli, P.C.; Munshi, G. and Gilbert, R. J. (1982): Identification and characterization of Bacillus cereus and other Bacillus species associated with food poisoning. In: Isolation and Identification Methods for Food poisoning Organisms. Corry. J.E.L. :Roberts. D. and Skinner. F.A. (eds.). Academic press. London and Nev. York.

- Lamps, L. W.; Medhusudhan, K.T.; Greenson, J.K.; Pierce, R.H.; Massoll. Ml.; Chiles, M.C.; Dean, P.J. and Scott, M.A. (2001): Yersinia pseudorubc'rczdosis in granulomatous appendicitis: a histologic and molecular study. Am. J. Surg. Pathol. 25(4): 508-515.

- Lindback, T.; Fagerlund, A.; Rodland, MS. and Granum, PE. (2004): Characterization of the bacillus cereus Nhe enterotoxin. Micrcbiol., I 50 (pt12):3959-67.

- Marks, AL 1,. (1980): Yersinia enterocolitica gastroenteritis: a prospective study of clinical, bacteriologic and epidemiologic features. J. Pediatrics, 96: 26-31.

- Mead, G.C.; Paezdelleon, L. and Adams, B.W. (1981): A study of rapid and simplified confirmatory tests for Clostridium perfringens. J. Appl. Bacteriol. 51: 355-361.

- Nakamura, M.; Kato, A.; Tanaka, D.; Gyobu, Y.; Higaki, S.; Karasawa, T. and Yaniagishi, T. (2004): PCR identification of the plasmid-borne mterotoxin gene (cpe) in Clostridiumperfringens strains isolated from food poisoning outbreaks. Int. J. Med. Microbiol. 294 (4): 261-5.

- Pirhonen, T.I.; Andersson, M.A.; Jaaskelainen,E.L.; Sakinoja-salonen, M.S.; Honkanon-Buzalski, T. and

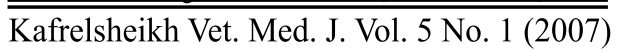


Johansson, T.M.-L.(2005): Biochemical and toxic diversity of Bacillus cereus in a pasta and meat dish associated with a food poisoning case. Food Microbiol. 22: 87-91.

- Quinn, P.J.; Carter, M.E.; Markey, B.K. and Carter, G.R. (1994): Enterobacteriaceac In: Clinical Veterinary Microbiology. Wolfe Publishing, PP. 209-236.

- Rabinovitz, M. (1987): Yersinia enterocolirica infection complicated by intestinal perforation. Archiv. Intern. Med.. 147: 1662-1663.

- Ryser, E.T. (1998): Public health concerns. In. Marth, E.H. and Steel, J.L.: Applied Dairy Microbiology. Marcel Oekker Inc. New York. pp. 263-404.

- Semedley, JG.; Fisher, DJ.; Sayeed, S.; Chakrabarti, G. and McClane, BA. (2004): The enteric toxins of Clostridium peifringens. Rev. Physiol. Biochem. Pharmacol. 152: 183-204.

- Strobel, E.; Heesemann, .1.; Mayer, G.; Peters, J.; MullerWeihrich, S. and Emmerling, P. (2001): Bacteriological and serological findings in a futher case of transfusion-mediated Yersinia enterocolitica. J. Clin. Microbiol., 38 (7): 2788-2790.

- Taylor, JM.; Sutherland, AD.; Aidoo, KE. and Logan, NA. (2005): Heat-stable toxin production by strains of Bacillus cereus, Bacillus firmus, bacillus megaterium, Bacillus simplex 
and bacillus licheniformis. FEMS Microbiol. Lett. 242 (2): 313-7.

- Varnam, A.H. and Sutherland, J.P. (1994): concentrated and dried milk products. In: Milk and Milk products. Technology, chemistry and microbiology. $1^{\text {st }}$ Ed., Chapman and hall, London, pp: 103-158.

- Vought, K.J. and Tatini, S.R. (1998): Salmonella enteritidis contamination of ice cream associated with a 1994 multistate outbreak. J. Food Prot. 61, 5-10.

بعض ميكروبات التسمم الغذائى فى الأيس كريم المباع جائلياً فى محافظة الإسكندرية

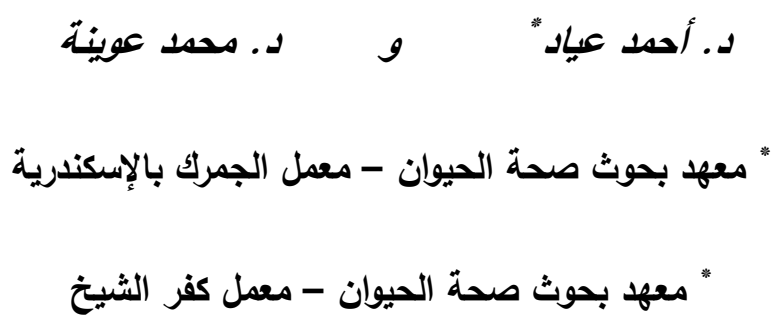

يعتبر الأيس كريم من المتلجات اللبنية المحببة من الجميع وخاصة الأطفال, إلا أنه قد يشكل خطورة على صحة الإنسان مما قد يحمله من بعض الميكروبات المسببة للنسمم الغذائى لذلك فقط أجريت هذه الدراسة لمعرفة مدى تواجد بعض الميكروبات الممرضة فى عدد ستون عينة من الأيس كريم المطعمة بالثيكولاتة والفراولة والفانيليا (20 عينة من كل نوع) والتى نم جمعهم بطريقة عشوائية من الباعة الجائلين بمدينة الإسكندرية وقد أسفرت النتائج عن نواجد ميكروب Bacillus Cereus بنسب

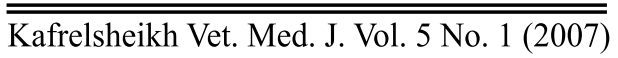


20 , 25 , 15\% فى عينات الأيس كريم المطعمة بالثنيكولاتة والفراولة والفانيليا على التوالى. بينما كان تواجد Clostridium Perfringens بنسب 10 , 15 , 100\% على التوالى. أما ميكروب الإيشيريكية القولونية فكانت نسبة تواجده فى العينات هى 20 , 25 , 15\% على التوالى.

كما أثثب النتائج أن 30 , 25 ، 20\% من العينات غير مطابقة للمواصفات القياسية المصرية بالنسبة إلى ميكروب المكور العنقودى الذهبى. كما تم عزل ميكروب اليارسينيا بنسبة 1\% من عينات الأيس كريم المطعمة الفراولة. تم مناقثة النتائج وخطورة الميكروبات المسببة للتسمم الغذائى والمعزولة من العينات من الناحية الصحية والاقتصادية. 